Agency and

Administration

\section{at loggerheads}

\section{Washington}

The State Department and the Nuclear Regulatory Commission (NRC) are drifting towards loggerheads on antiproliferation safeguards. Both parties agree that the safeguards administered by the Vienna-based International Atomic Energy Agency (IAEA) need to be improved. The State Department, reflecting a general drift away from the policies of the Carter Administration, would prefer to use conventional diplomatic channels.

In contrast NRC, which under the Nuclear Non-Proliferation Act signed by President Carter in 1978 is required to assure Congress about the adequacy of IAEA safeguards, is pushing for a more direct approach. Following sharp criticism of IAEA procedures by two former inspectors (Nature 26 November, p.300), the five members of the commission have sent a letter to all members of Congress saying that the current safeguards system "would not detect a diversion in at least some types of facilities".

In the light of this concern and the general shadows that have recently been cast over the adequacy of IAEA safeguards, NRC has decided to carry out a review of its own policies on granting export licences for nuclear materials. The State Department, however, although embarrassed by disclosures about weaknesses in IAEA's safeguards system, does not seem to feel any such drastic action is necessary. Addressing the Senate Foreign Relations Committee last week, $\mathrm{Mr}$ Richard T. Kennedy, Under-Secretary of State for Management and a former member of NRC, repeated the Administration's commitment strongly to support the agency.

Introducing the Senate hearings, committee chairman Senator Charles Percy emphasized the central importance of IAEA, and pushed Mr Kennedy hard on whether the Administration was doing everything it could to prevent the spread of nuclear military technology, complaining that the Senate had been provided with insufficient information on procedures agreed with Pakistan and IAEA to prevent the diversion of civilian technology. Senator Percy put the suggestion strongly denied by Mr Kennedy - that the Administration might be going "soft" on non-proliferation to help boost the sagging exports of the domestic nuclear industry.

Democrat Senator John Glenn went even further, suggesting that the State Department should put pressure on other industrialized countries to provide a significant increase in technical and financial resources for the agency. To support his argument that such increases were badly needed, Mr Glenn produced a report prepared at the Pacific Northwest Laboratory under contract to the Department of Energy throwing doubt on whether IAEA was able to achieve its technical objectives of the surveillance and accounting of nuclear materials.

One issue on which there was little disagreement between Senator Percy and the Administration was over attempts by

\section{Is creation a science or a religion?}

\section{Little Rock}

The state of Arkansas was accused on Monday morning of making "an unprecedented attempt to legislate what is science" at the opening of a trial over its efforts to determine how different theories of the origins of man should be taught in its public schools.

The American Civil Liberties Union (ACLU) is challenging as unconstitutional a law, passed by the state legislature earlier this year, which requires that whenever the Darwinian theory of evolution is taught, an equal amount of time should be devoted to presenting evidence in favour of what is described as "creation science".

ACLU contends that the law violates the first amendment to the constitution, which requires a strict separation of church and state. It argues, in the words of Little Rock attorney Robert M. Cearley, that "creation science is not science but religious apologetics, an attempt to prove or justify sectarian religious beliefs". The state argues that there is nothing inherently religious in teaching that the world came into being as the result of a positive act of creation, and that the evidence used to support this hypothesis is "at least as scientific" as the evidence for the "evolution science".

Setting the agenda for a debate that is likely to dominate the trial, state attorneygeneral Stephen Clark responded in his opening statement that "this is not a trial about religion but a trial about science".

In 1968, the United States Supreme Court struck down as unconstitutional a state law forbidding the teaching of evolution on the grounds that it contradicted a literal interpretation of the Bible. This time the issue has been reversed. ACLU has brought the case on behalf of 23 local religious leaders, biology teachers and schoolchildren, claiming that the new law infringes their rights to freedom of religion.

"For practical purposes it is a tremendously important case for us because it is the first of its kind, and the
Third World countries to gain greater influence on the activities of IAEA, both in terms of increasing their membership of the governing council and in appointing more inspectors from the developing nations. On the latter point it was agreed that, although an important objective, it should not be pursued at the price of sacrificing the quality of inspection procedures. On the other hand, Mr Kennedy made it clear that the State Department would resist attempts to "politicize" the agency, in terms of changing the current balance of control.

There is a deeper division over the extent to which a lack of detailed information about the technical data used by IAEA in

decision of the court will get a lot of attention", said ACLU staff attorney Jack Novick before the case started. He pointed out that a similar bill has recently been passed in Louisiana, and that others are pending in up to twenty more states.

Three complaints are being made by ACLU. The principal charge is that the law violates the first amendment to the constitution. It is also being charged that the law infringes the academic freedom of teachers and schoolchildren, since it imposes conditions under which evolution can be taught; and that the language in the bill is unconstitutionally vague.

The state attorney-general in disputing each of these charges claims that, since there is nothing necessarily religious in the idea that the world came into being at the hands of some undefined form of creator, there is no problem with the constitution.

Each side will introduce a string of scientific witnesses to support its case. For ACLU, these include prominent academics in fields such as biology, geology and palaeontology; the state plans to introduces qualified scientists who claim their results substantiate the creationist theory of origins. Furthermore, unlike previous cases in which the relative merits of the two explanations were directly compared, this time the focus will be as much on the philosophy of science, with Judge William Overton deciding what types of ideas and reasoning can be described as "scientific" and "religious".

The case is expected to last for two weeks. If ACLU loses, it is already promising that it considers the case so important that it will take it as far as the Supreme Court, which has ultimate say on constitutional issues.

If the civil liberties group wins, then $\mathrm{Mr}$ Novik says it will press for full payment of its legal costs - calculated to be several hundred thousand dollars - against the state of Arkansas. But in that case, the state is expected to appeal against the verdict. So either way, the full legal debate is likely to last for a long time.

David Dickson 
reaching many of its conclusions makes it difficult to check on whether the agency is doing a good job. NRC member Mr Victor Gilinsky expressed concern that protection given in IAEA statutes to industrial, secret or other confidential information has been interpreted in the broadest manner to withhold information about the safeguards system.

Suggesting that undue secrecy made it difficult for NRC to fulfil its responsibilities for checking the adequacy of IAEA safeguards - responsibilities whose legal status still remains ambiguous - $\mathrm{Mr}$ Gilinsky said that the commission believed more information should be reported to IAEA's board of governors by its secretariat, and that the United States should try to obtain better information on overall international safeguards effectiveness and on any significant safeguards problems in countries receiving US exports.

$\mathrm{Mr}$ Kennedy replied that the general limitations on the agency's role - such as the substantial amount of classified information which it could not release are "simply facts of international relations. . . The IAEA safeguards system entails a unique compromise of sovereign rights by many nations, and it is certainly no surprise that this compromise is subject to specific limitations". David Dickson

\section{Germany's breeder \\ Gap unbridged}

\section{Ulm, West Germany}

Rapidly rising costs are threatening the future of West Germany's SNR-300 fastbreeder reactor, with government and public service utility companies still arguing over who should foot the the increased bill if the project is to continue.

The Minister of Research and Technology, Andreas von Bülow, has succeeded in extracting from the utilities an increased financial contribution to the SNR-300 plant at Kalkar. At the end of October he announced that Rheinisch-Westfalisches Elektrizitatswerk (RWE), the leader of the owner/operator utility group, is willing to put up an additional DM 375 million. Two other utilities not so far involved in the project, Preussenelektra and Nordwestdeutsche Kraftwerke (NWK) are prepared to contribute DM 172 million.

Even so these pledges fill only half of a total shortfall of DM 1,100 million created by recent cost overruns. The federal government is unwilling to provide the extra funds from its own budget, and insists that the full amount should be paid by West German industry and in particular by the utilities, each financing a fraction corresponding to its share of electricity generation. "It is perfectly clear," von Bulow recently said, "that without an increase in the participation of the utilities, the future of the fast breeder is in danger and a halt to construction before the end of the year cannot be ruled out"
The weeks ahead will show whether von Bulow's warning is merely a tactical ploy or whether there is a real chance that work on the fast breeder will stop. Although budgetary problems have triggered off this latest confrontation, if the minister regarded the fast breeder as an absolute economic necessity it seems likely that he could accommodate the necessary additional DM 550 million over five years (DM 110 million a year) within this present budget - the ministry has a proposed total budget of DM 6,600 million for 1982 and an energy research budget of DM 2,550 million. "The present situation," he said, "necessitates a reconsideration of the original objectives of government support." At the same time the minister announced that government funds for microelectronics and biotechnology will be increased over the next few years.

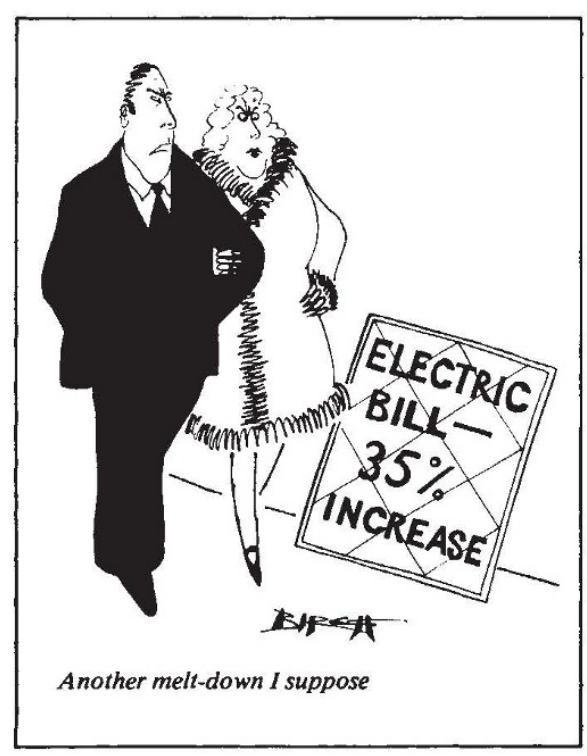

Political uncertainty is one of the reasons why the utilities are reluctant to shoulder an increased share of SNR-300 costs. The Bundestag has reserved to itself the decision on whether the SNR-300 should be put into operation when completed. The utilities hesitate to commit themselves as long as this uncertainty persists, and the pledges made so far are contingent, among other conditions, on a positive decision from the Bundestag.

Licensing uncertainties have been another major obstacle - but here at least the greatest difficulties appear to have been overcome with the passing of the fourth part of the licence on 15 October.

Some utility companies originally argued that SNR-300 is a national project that should be financed from taxpayers' money. It remains to be seen whether they will soften their stand in the face of a threat to abandon the project. The West German utility association, VDEW, is now discussing alternative finance strategies including a research and development levy on electricity sales modelled on the present subsidy for West German coal used in the generation of electricity.
Israeli education

\section{More gloom}

\section{Tel Aviv}

The complaint that cuts in higher education could seriously endanger Israel's scientific potential in the 1990 s ran through the symposium organized at the end of November by the Israeli popular science magazine Mada to celebrate its twentyfifth anniversary. Ironically, the symposium coincided with the Isratech exhibition, a celebration of recent Israeli achievements in applied science.

While Isratech celebrated the succcess of Israel's funding policy, which for the past decade has emphasized applications, symposium participants maintained that, unless investment in higher education is stepped up, Israel's advantage in many sectors of technology could prove short-lived. The symposium was chaired by the physical chemist Dr Ephraim Katzir, formerly Katchalski, who produced the 1968 report which effectively switched government emphasis from pure to applied research.

Unlike other new states, Israel has a research infrastructure which antedates independence and which is based on institutions such as the Technion, the Weizmann Institute, the Hebrew University and the Volcani Agricultural Institute. Until the late 1960 s, Israeli science policy was aimed at more of the same. The Kachalski report redirected government attention to the needs of industry. Only some of Katchalski's recommendations were implemented. Chief scientists were established in ministries involved in research and development, but the proposed upgrading of the National Council for Research and Development failed to materialize - indeed, in 1977, it was actually downgraded, being transferred from direct responsibility to the Prime Minister's Office to the new Ministry of Energy and Infrastructure. At the same time, all spending on research has been eroded by inflation, now 133 per cent a year.

Even so, the post-Katchalski era has produced a number of achievements. Industry has done well, and now employs more science graduates. Agriculture has seen a steady stream of advances in crop breeding, soil chemistry, irrigation techniques and such novel methods as the sterilization of soils by solar energy. Both production and productivity have increased.

The symposium was chiefly alarmed by the other side of this coin - the continuing absence of a national science policy and the continuing brain-drain to the United States and Europe. The participants blamed people's willingness to leave on the cutbacks in university finance and the mismatch between what universities teach and what industry (and students) demands.

In the past ten years, there has also been a stagnation of student numbers in the exact sciences while total student numbers have soared. The underlying reason is not 